obituary

\section{A. J. Young}

Mr C. A. J. Young F.R.S., died on 20 January 1978 at the age of 65 . Mr Young (Christopher at home but A. J. at work) was the fourth President of the Institute of Measurement and Control from 1954 to 1957 and a recognised authority in that area of technology. He was head of the ICI Central Instrument Research Laboratory for some 25 years and the author of a definitive textbook on the fundamentals of automatic process control.

His achievements were recognised by the award of an Honorary D.Tech. by the University of Bradford in 1968, the award of the first Sir Harold Hartley medal by the Institute of Measurement and Control in 1969 and Honorary Fellowship of that institute in 1973. In 1972 he became a Fellow of the Royal Society.

Born on 7 March 1912, he read physics at Oxford and after taking his BA in 1932 he worked for a year in Professor Townsend's research group, gaining his B.Sc. for work on electrical discharges in gases at low pressures. $\mathrm{He}$ then turned to teaching and was a master at Cheltenham for some four years before joining the Meteorological Service in 1938. This work took him to the Sudan where he was involved in the establishment of meteorological stations, particularly to support the African services of Imperial Airways. $\mathrm{He}$ returned to England at the outbreak of war, hoping to join Coastal Command as he already had some flying experience; but the Air Ministry perceived a more effective use for a scientifically qualified meteorologist as part of their joint research project with ICI for fog dispersion on airfields (FIDO).

In 1940 he joined the Chemical Engineering Research Section of ICI (Fertiliser and Synthetic Products) Ltd at Billingham, his first major involvement with instrumentation. $\mathrm{He}$ joined the Billingham 'Tube Alloys' nuclear engineering team on its inception and found himself responsible for the instrument side of the project. From then on instrumentation and control became his main interest, particularly in relation to chemical engineering activities, and he was to work with ICI in this field until his retirement in 1973.

He left Billingham in 1946 to work in the Technical Department of the ICI Head Office in London. The Technical Director, F. E. (later Sir
Ewart) Smith, made him responsible for establishing the ICI Central Instrument Section with a small laboratory facility at The Frythe in Welwyn, Herts.

This began the most productive part of his career. A. J.'s greatest strengths lay in his ability to recognise technical areas where exploration could be fruitful, to select good lieutenants, to listen to them, to give them freedom and support, and to enlist the support of unbelievers. The new laboratory was quickly established with great enthusiasm and, it seemed, with a complete disregard of the procedural obstacles that usually characterise large organisations. There was early work on the development of techniques for on-line analysis and quality control but the work of the laboratory soon focused on the substitution of understanding for empiricism in the application of automatic process control. The next few years showed a steady growth and by 1956 the group had outgrown its Welwyn facilities and moved to Bozedown House near Pangbourne in Berkshire. By this time its name was well-established. The laboratory and A. J. with it had developed an international reputation and saw a steady stream of visitors from Britain and overseas who regarded it as a major centre of process control technology.

Within a short time after the move to Bozedown House A. J. Young established the first digital computing service at Wilton which led to the introduction of computers all through the Company and again, it was his first computer-controlled pilot plant which led to the installation at the Alkali Division at Fleetwood of one of the first large scale computer-controlled plants in the world.

Following an ICI Head Office reorganisation, what had been an independent Central Instrument Research Laboratory was amalgamated with the Petrochemical and Polymer Laboratory to form the new 'Corporate Laboratory' and A.J. became Technical Director of the Corporate Laboratory-Bozedown. After his retirement in 1973 the new laboratory was to be unified with a new and broader emphasis, in a single location at Runcorn in Cheshire, thus ending an era which his friends and colleagues will always associate with their memories of him.

A. J.'s final illness was relatively short but over recent years he must have suffered much pain and his friends will not forget his courage in disregarding it to the end.

We extend our sympathy to his widow and stepdaughters.

J. R. Halsall

J. D. Tallantire

\section{J. W. McLeod}

EMERITUS Professor James Walter McLeod, O.B.E. F.R.S., F.R.S.E., F.R.C.Path., born on 2 January 1887 at Dumbarton, died in his 92nd year on 11 March 1978.

After graduating from Glasgow Medical School in 1908 he held a Coats, and later a Carnegie scholarship in Robert Muir's Department of Pathology. From 1912 he was Assistant Lecturer in Pathology at Charing Cross Hospital Medical School until he joined the R.A.M.C. at the outbreak of war in 1914. At the end of war he was Captain in charge of the 8th Mobile Laboratory in France and had published papers on trench fever and nephritis, bacillary dysentery and the incidence of Pfeiffer's influenza bacillus in pandemic influenza. In 1919 he became Lecturer in Bacteriology in Leeds and in 1921 the first occupant of the Brotherton Chair in Bacteriology, which he held until his retirement in 1952.

From his war experiences stemmed his interest in anaerobic gas gangrene bacilli, and from this in turn his preoccupation with bacterial respiration. In a series of 14 papers published betwen 1921 and 1929, mostly in collaboration with J. Gordon and sometimes others, with only a few exceptions published in the Journal of Pathology and Bacteriology, he explored the reducing mechanism of aerobic and anaerobic microorganisms, the production of $\mathrm{H}_{2} \mathrm{O}_{2}$ by anaerobic bacteria and by aerobic bacteria devoid of catalase and the colour changes they produced in haemoglobin or in benzidine blood media under these conditions. Two of these papers dealt with the oxidase reaction of bacterial colonies. McLeod's simplified technique and the second stage development of a bluish-black pigment by gonococcus colonies observed when $p$-phenyline diamine was used as indicator dye in the oxidase reaction so revolutionized the laboratory diagnosis of clinical gonorrhoea that he achieved an international reputation. The work on bacterial respiration culminated in McLeod's contributing chapters on the 